\title{
Incidence of Inflammatory Bowel Disease in a Tertiary Centre of Eastern India
}

\author{
Bhaswati C Acharyya ${ }^{1 *}$, Saumyabrata Acharyya ${ }^{2}$ and Hema Chakrabarty ${ }^{3}$ \\ ${ }^{1}$ Consultant Paediatric Gastroenterologist, AMRI Hospitals, India \\ ${ }^{2}$ Consultant Paediatrician, AMRI Hospitals, India \\ ${ }^{3}$ Consultant Histopathologist, AMRI Hospitals, India
}

Submission: June 11, 2018; Published: June 26, 2018

"Corresponding author: Bhaswati C Acharyya, Consultant Paediatric Gastroenterologist, AMRI Hospitals, Kolkata, India, Email: bukuli2@hotmail.com

\section{Mini Review}

Inflammatory Bowel disease is rising all over the world. India is no exception. Recently all the tertiary referral centres of India are diagnosing Inflammatory Bowel Disease (IBD) specially Crohn's Disease at an increased rate compared to yester years. The following study is carried out to see the incidence and prevalence of Inflammatory Bowel disease in Children in a tertiary centre of Eastern India.

\section{Methods}

A retrospective analysis of the case records of children, aged 1 year to 18 years attending the Paediatric Gastroenterology department of a tertiary centre of Kolkata was done from January 2017 to December 2017. All these children attended the outpatients department or were admitted as inpatient due to various gastrointestinal symptoms such as abdominal pain, diarrhoea, bloody diarrhoea, weight loss, loss of energy and poor appetite, deranged liver functions etc. All the case records were carefully analysed to find out all the children who after all the investigations were diagnosed to have Inflammatory Bowel disease. Inflammatory Bowel disease was diagnosed (using Porto criteria) after carrying out Endoscopies and looking at the Histopathology from the biopsies taken from Ileum, colon, rectum, stomach \& duodenum. MR enterogram or CT enteroclysis was done in all cases to evaluate the small bowel.

\section{Results}

Total of 933 patients attended the GI care. Among those children investigations revealed new Inflammatory Bowel Disease in 13 children- 7 girls and 6 boys. Distribution of Ulcerative colitis, Crohn's Disease and IBD Unclassified were as follows

\begin{tabular}{|c|c|}
\hline Type of IBD & No of Children (\%) \\
\hline Crohn's Disease & $9(69.2 \%)$ \\
\hline Ulcerative Colitis & $2((15.4 \%)$ \\
\hline IBD-U & $2(15.4 \%)$ \\
\hline
\end{tabular}

The incidence of Inflammatory Bowel disease in children in this centre was found to be 13.9/1000 children in the year 2017 .

\section{Discussion}

IBD is occurring much more commonly in India than previously thought of [1]. This is a hospital based statistics of a crude incidence of IBD in children. The first national prospective survey of childhood IBD from the British Isles documented an incidence of 5.2/100,000 children aged less than 16 years per year [2]. There is lack of community based studies in India involving children. But this tertiary centre based study reflects clearly the increased incidence of IBD in children and an incidence of 13.9/1000 children is comparable with the west.

\section{Conclusion}

IBD specially Crohn's Disease in children is increasing all over the world. India is not an exception. Paediatricians should be well aware of this fact and should have high index of suspicion to diagnose IBD early to avoid future complications.

\section{References}

1. Ray G (2016) Inflammatory bowel disease in India-past, present and future. World J Gastroenterol 22: 8123-8136.

2. Ravikumara N, Sandhu BK (2006) Epidemiology of inflammatory bowel diseases in childhood. Indian J Pediatr 73(8): 717-721. 


\section{Your next submission with JuniperPublishers} will reach you the below assets

- Quality Editorial service

- Swift Peer Review

- Reprints availability

- E-prints Service

- Manuscript Podcast for convenient understanding

- Global attainment for your research

- Manuscript accessibility in different formats ( Pdf, E-pub, Full Text, audio)

- Unceasing customer service

Track the below URL for one-step submission https://juniperpublishers.com/online-submission.php 